\title{
Necrotizing Pneumonia in a Diabetic Child Successfully Treated with Pneumonectomy
}

\author{
Pnömonektomi ile Başarılı Bir Şekilde Tedavi Edilen Nekrotizan Pnömonili Diyabetik \\ Çocuk
}
(D) Gürkan Atay¹, (D) Manolya Kara², (D) Emine Çalışkan³, (D) Feryal Gün Soysal4, (D Selda Hançerli Torun², (D) Ayper Somer2 (D) Kemal Nişli1, (D) Agop Çıtak1

1istanbul University Faculty of Medicine, Department of Pediatric Intensive Care, İstanbul, Turkey

2istanbul University Faculty of Medicine, Department of Pediatric Infectious Diseases, İstanbul, Turkey

3istanbul University Faculty of Medicine, Department of Pediatric Radiology, ístanbul, Turkey

${ }_{4}^{4}$ istanbul University Faculty of Medicine, Department of Pediatric Surgery, İstanbul, Turkey

\begin{abstract}
Diabetic patients may experience more severe Staphylococcus aureus-related respiratory tract infections such as necrotizing pneumonia (NP). A 13-year-old girl with uncontrolled diabetes mellitus was admitted to pediatric intensive care unit (PICU) with diabetic ketoacidosis and respiratory distress. Her initial evaluation revealed diffuse pneumonic infiltration that progressed to NP within days. She was intubated and placed on mechanical ventilator (MV) support. Positive inotropes and broad-spectrum antibiotics were initiated. Methicillinresistant S. aureus was isolated from blood and pleural specimen cultures. In spite of aggressive medical treatment, infection could not be controlled and lobectomy was performed. However, the patient was fistulized and right total pneumonectomy was performed on the $16^{\text {th }}$ and $29^{\text {th }}$ days of PICU admission. She gradually got better and was weaned from MV. On the $59^{\text {th }}$ day, she was discharged oxygen-free from the hospital. Early surgical intervention should be considered for the treatment of NP resistant to medical therapy.
\end{abstract}

Keywords: Diabetes, child, necrotizing pneumonia, pneumonectomy öz

Diyabetik hastalar, nekrotizan pnömoni (NP) gibi daha ağır seyirli Staphylococcus aureus ile ilgili solunum yolu enfeksiyonları yaşayabilirler. Düzensiz takipli diabetes mellitus tanılı 13 yaşındaki kız hasta, diyabetik ketoasidoz ve solunum sıkıntısı tanılarıyla çocuk yoğun bakım ünitesine (ÇYBÜ) yatırıldı. Illk değerlendirmesinde pnömonik infiltrasyon tespit edilen hasta NP tanısıyla entübe edildi ve mekanik ventilatör (MV) desteğine bağlandı. Pozitif inotrop ve geniş spektrumlu antibiyotikler bașlanıldı. Kan ve plevral örnek kültüründe metisiline dirençli S. aureus üremesi görüldü. Agresif medikal tedaviye rağmen enfeksiyonu kontrol altına alınamayan hastaya lobektomi yapıldı. Fistülize olan ve hayatı tehlikesi devam eden hastaya ÇYBÜ'ye yatışının 16 ve 29. günlerinde sağ total pnömonektomi ameliyatları yapıldı. Kliniğinde iyileșme görülen ve MV'den ayrılan hasta 59. günde hastaneden oksijensiz taburcu edildi. Medikal tedaviye dirençli NP tedavisinde erken cerrahi girișim hayat kurtarıcı olabilir.

Anahtar Kelimeler: Diyabet, çocuk, nekrotizan pnömoni, pnömonektomi

\section{Introduction}

Diabetes mellitus (DM) is a metabolic disorder that has been reported with increasing incidence in children. It is estimated that approximately 65.000 new cases under the age of 15 are diagnosed each year in the world (1). Diabetic children, particularly those with uncontrolled diabetes, are more prone to infectious diseases including skin and soft tissue structures, urinary tract and respiratory system when compared to healthy subjects (2).
Staphylococcus aureus is an important cause of respiratory tract infections. Especially, methicillin-resistant strains can lead to progressive necrotizing pneumonia (NP) with a high mortality rate (3). Although medical and supportive therapy remains the first-line treatment options, early surgical interventions should be performed in resistant cases (4).

Herein, we report a child with uncontrolled type 1 DM who was hospitalized in pediatric intensive care unit (PICU) for NP that was successfully treated with right total pneumonectomy.
Address for Correspondence/Yazıșma Adresi: Gürkan Atay MD, İstanbul University Faculty of Medicine, Department of Pediatric Intensive Care, İstanbul, Turkey

Phone: +90 2164142000 E-mail: drgurkanatay@yahoo.com ORCID ID: orcid.org/0000-0002-0317-5872

Cite this article as/Atıf: Atay G, Kara M, Çalışkan E, Soysal FG, Torun SH, Somer A, Nişli K, Çıtak A. Necrotizing Pneumonia in a Diabetic Child Successfully Treated with Pneumonectomy. İstanbul Med J 2019; 20(4): 352-5.

(C) Copyright 2019 by the Istanbul Training and Research Hospital/istanbul Medical Journal published by Galenos Publishing House.

(C) Telif Hakkı 2019 Istanbul Ĕgitim ve Araștırma Hastanesi/Istanbul Tıp Dergisi, Galenos Yayınevi tarafından basılmıștır.
Received/Geliș Tarihi: 12.10 .2018 Accepted/Kabul Tarihi: 26.12.2018 


\section{Case Report}

A 13-year-old female was admitted to PICU with the preliminary diagnoses of respiratory distress and diabetic ketoacidosis. Her medical history revealed that she was diagnosed as type 1 DM at the age of 8 years and was on subcutaneous insulin treatment. However, she was irregularly followed-up because of non-compliance.

On presentation, she was confused and agitated. Her Glasgow Coma scale score was 10 and her vitals were as follows: heart rate: 139/min, blood pressure: $107 / 57 \mathrm{mmHg}$ and respiratory rate: $45 / \mathrm{min}$. She was dyspneic and severely dehydrated. Her respiratory sounds were diminished at the right middle zone and percussion revealed dullness. Other system examinations were unremarkable.

In the laboratory evaluation, white blood cell count was $13.000 / \mathrm{mm}^{3}$ (neutrophil 87\%). Acute phase reactants were significantly increased [C-reactive protein: $545 \mathrm{mg} / \mathrm{L}$ (normally $<5$ ) and procalcitonin: 43.56 $\mathrm{mcg} / \mathrm{L}$ (normally <0.02)]. Metabolic acidosis was detected in venous blood gas analyses $\left(\mathrm{pH}=7.07, \mathrm{CO}_{2}=19.8 \mathrm{mmHg}, \mathrm{HCO}_{3}=5.7 \mathrm{mmol} / \mathrm{L} \mathrm{BE}=-\right.$ $23.7 \mathrm{mmol} / \mathrm{L}$ ). Plasma blood glucose was $628 \mathrm{mg} / \mathrm{dL}$. She was intubated and placed on pressure support-synchronized intermittent mandatory ventilation (PS-SIMV) with the following settings: positive inspiratory pressure: $20 \mathrm{CmH}_{2} \mathrm{O}$, frequency: 22/min, I/E ratio:1:2.4 and positive endexpiratory pressure: $7 \mathrm{cmH}_{2} \mathrm{O}$.

In addition to pleural effusion, chest radiography showed diffuse pulmonary opacity with air bronchogram in the right lung, dominantly in the lower zone (Figure 1A). Intravenous hydration, bicarbonate and insulin therapies were started. After blood cultures were taken, empirical teicoplanin $(10 \mathrm{mg} / \mathrm{kg} /$ dose loading, with 12-hour intervals for 3 times, then $10 \mathrm{mg} / \mathrm{kg} / \mathrm{day}$ ) and meropenem (100 mg/kg/day) were initiated. Tube thoracotomy drainage was performed and exudative pleural specimen was sent for culture. She was started dobutamine (10 $\mathrm{mcg} / \mathrm{kg} / \mathrm{min})$ and noradrenaline $(0.1 \mathrm{mcg} / \mathrm{kg} / \mathrm{min})$ perfusion due to refractory hypotension. Echocardiographic examination was normal. Amikacin (15 mg/kg/day) and fluconazole (10 mg/kg/day) were added due to worsening medical condition. Abdominal ultrasonography was normal except for grade 1 renal parenchymal damage. Hemoglobin A1 level was $9.2 \%$.

On follow-up, blood and pleural specimen cultures yielded methicillinresistant S. aureus (MRSA) growth. Teicoplanin was tapered to linezolid (10 mg/kg/dose, three times a day) therapy. However, fever and increased acute phase response persisted. Chest computerized tomography (CT) performed on the $7^{\text {th }}$ day revealed consolidation in the right middle and lower lobe, which evolved into necrosis and pneumatocele with accompanying pleural fluid (Figure 1B). She was tapered to subcutaneous insulin treatment after blood glucose control was achieved.

On the $10^{\text {th }}$ day of PICU admission, the thorax tube was extracted. However, she was still febrile and dependent on intensive support MV. On the $12^{\text {th }}$ day, the radiologic features were complicated by large cavitation in the right lower lobe and a newly developed bronchopneumonic infiltrative lesion in the left lower lobe (Figure 1C). Linezolid was stopped after 10 days and vancomycin was started $(60 \mathrm{mg} / \mathrm{kg} /$ day). Despite aggressive medical treatment, infection could not be localized and right lower lobectomy was performed on the $16^{\text {th }}$ day of admission.
On follow-up, tracheal aspirate specimen culture yielded Stenotrophomonas maltophilia and Candida albicans growth. Meropenem was stopped. Fluconazole was tapered to caspofungin therapy (50 mg/ $\mathrm{m}^{2} /$ day after a loading dose of $70 \mathrm{mg} / \mathrm{m}^{2}$ ), and ciprofloxacin $(20 \mathrm{mg} /$ $\mathrm{kg} /$ day) and trimethoprim (TMP)-sulfamethoxazole (12 mg TMP/kg/day) were added.

On the $24^{\text {th }}$ day, she experienced a sudden decrease in hematocrit levels. Control chest CT was performed on suspicion of pulmonary hemorrhage. In addition to newly developed bronchiolar infiltration in ground glass opacities in the right lower lobe, hemorrhagic fluid collection was observed in the right hemithorax (Figure 1D). She was given erythrocyte and plasma transfusion, and pentaglobulin treatment $(5 \mathrm{~mL} / \mathrm{kg} /$ day for five days). Meanwhile, tigecycline (1.2 mg/kg/dose every 12 hours) was added.

A multidisciplinary council of pediatric and chest surgeons agreed on the necessity of right pneumonectomy because of progressive course. On the $29^{\text {th }}$ day, right pneumonectomy and tracheostomy operations were performed. During follow-up, bronchoscopy was performed because of insufficient ventilation and suspected air leak on chest X-ray, and parenchymal fistula was detected in the right residual segment. On the $41^{\text {th }}$ day, fistula closure was performed.

Postoperative control chest X-ray and CT revealed that right lung was totally removed. Also, there was no evidence of infiltration in the upper and lower lobes of the left lung, which was consistent with improvement (Figure 2A, B). Her general condition and ventilation improved over time. She was tapered to home ventilation on PS-SIMV mode, and then to continuous positive airway pressure support and
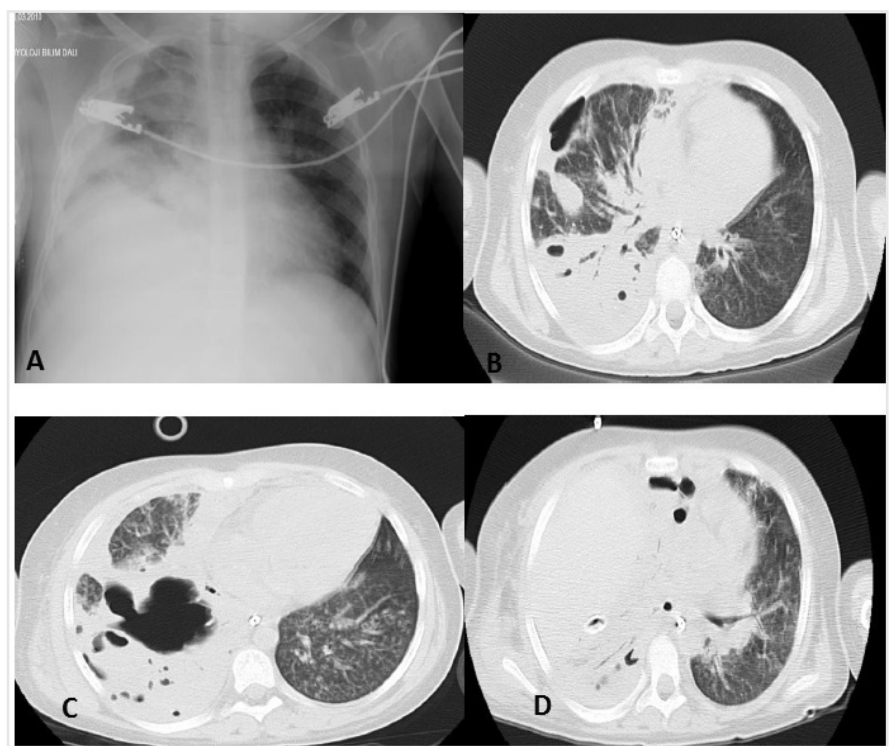

Figure 1A. Postero-anterior chest X-ray. Day 1, diffuse pulmonary opacity with air bronchogram and pleural effusion in the right lung. 1B. Computerized chest tomography (CT). Day 7, Consolidation in the right middle and lower lobe, which evolved into necrosis and pneumatocele with accompanying pleural fluid. 1C. CT. Day 12, large cavitation in the right lower lobe, newly developed bronchopneumonic infiltrative lesion in the left lower lobe. 1D. CT. Day 24, hemorrhagic fluid collection in the right hemithorax and newly developed bronchiolar infiltration in ground glass opacities in the right lower lobe 

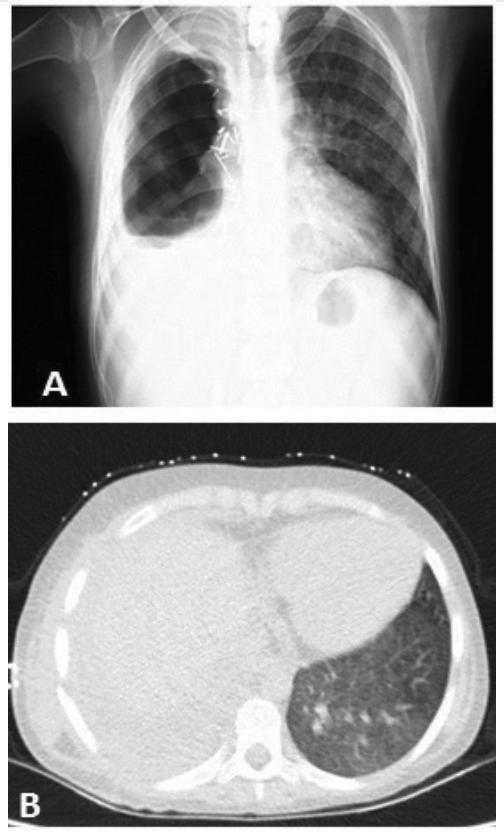

Figure 2A. Postero-anterior chest X-ray, 2B. Computerized chest tomography on day 42 , right pneumonectomy and prominent improvement in left lung

easy-breathe on the following days. On the $52^{\text {nd }}$ day of admission, she was transferred to inpatient clinic and discharged oxygen-free from the hospital one week later. Informed consent was obtained from the parents of the patient for publication.

\section{Discussion}

The incidence of community-acquired MRSA infections has been increasing in recent years (5). In addition, type $1 \mathrm{DM}$ is declared as a risk factor for S. aureus-related infections (5). Literature data agree that nasal colonization of S. aureus is a predisposing factor for infection and that there is an increased incidence of nasal S. aureus colonization in diabetic patients (6). Ahluwalia et al. (7) reported a positive correlation between hemoglobin A1 levels and incidence of nasal S. aureus colonization in diabetic patients. Similarly, our patient was diagnosed as type 1 DM five years ago and she was non-compliant with the proper follow-up, thus having a high hemoglobin A1 values.

MRSA-associated NP may have a potentially progressive and fatal course (3). Linezolid or glycopeptide antibiotics (vancomycin/ teicoplanin) should be included as part of the initial regimen to treat MRSA-related pneumonia (8). Tigecycline should be reserved for complicated cases and should be selected as the final option since it is not Food and Drug Administration (FDA) approved before 18 years of age (9). Our patient presented with respiratory distress secondary to community-acquired pneumonia. Since she was septic and distressed at presentation, empirical broad-spectrum antibiotherapy including teicoplanin was started initially. On her follow-up, empyematous material and blood culture revealed MRSA growth. As her pulmonary findings progressed under teicoplanin treatment, we preferred to taper linezolid because of its high penetration into lung tissue.
Despite effective medical treatment, persistent fever and respiratory distress should raise the suspicion of pulmonary necrosis (10) Similarly, chest CT confirmed NP in our patient. During follow-up, alternating vancomycin and finally tigecycline therapy was tried due to accompanying MRSA bacteremia. However, the progression of infection could not be inhibited.

Although medical and supportive treatment is preferred initially for the treatment of NP, surgery should not be delayed in resistant cases (4). The main indications for surgery include persistent fever, persistent respiratory distress, and sepsis despite aggressive medical treatment (11). The type of surgical resection is based on the extent of pulmonary necrosis and should be as conservative as possible. Thoracoscopic decortication without lung resection, wedge resection and lobectomy are the preferred surgical options (11). Pneumonectomy may be required if the necrotizing process involves multiple lobes (12). Because of the fulminant course of the infection, surgery was inevitable for our patient. Although lobectomy was tried initially, it was unable to control the infection. Therefore, pneumonectomy was performed. With the success of metabolic control, pneumonectomy was well-tolerated in our patient.

\section{Conclusion}

This case was reported to emphasize the importance of appropriate control of DM, in addition to awareness of early surgical consultation for patients with NP resistant to effective medical therapy.

Informed Consent: Informed consent was obtained from the parents of the patient for publication.

Peer-review: Externally peer-reviewed.

Author Contributions: Concept - G.A., M.K.; Design - G.A., E.Ç.; Supervision - F.G.S., S.H.T.; Data Collection and/or Processing - G.A., M.K., A.C..; Analysis and/ or Interpretation - A.S., K.N., A.Ç.; Literature Search - G.A., M.K. K.N.; Writing Manuscript - G.A., M.K.; Critical Review - A.S. S.H.T., A.C., K.N.

Conflict of Interest: No conflict of interest was declared by the authors.

Financial Disclosure: The authors declared that this study received no financial support.

\section{References}

1. DIAMOND Project Group. Incidence and trends of childhood type 1 diabetes worldwide 1990-1999. Diabet Med 2006; 23: 857-66.

2. Joshi N, Caputo GM, Weitekamp MR, Karchmer AW. Infections in patients with diabetes mellitus. N Engl J Med 1999; 341: 1906-12.

3. Spencer DA, Thomas MF. Necrotising pneumonia in children. Paediatr Respir Rev 2014; 3: 240-5.

4. Avansino JR, Goldman B, Sawin RS, Flum DR. Primary Operative Versus Nonoperative Therapy for Pediatric Empyema: A Meta-analysis. Pediatrics 2005; 115: $1652-9$.

5. Jacobsson G, Dashti S, Wahlberg T, Andersson R. The epidemiology of and risk factors for invasive Staphylococcus aureus infections in western Sweden. Scand J Inf Dis 2007; 39: 6-13. 
6. Wertheim HF, Melles DC, Vos MC, van Leeuwen W, van Belkum A, Verbrugh $\mathrm{HA}$, et al. The role of nasal carriage in Staphylococcus aureus infections. Lancet Infect Dis 2005; 5: 751-62.

7. Ahluwalia A, Sood A, Lakshmy R, Kapil A, Pandey RM. Nasal colonization with Staphylococcus aureus in patients with diabetes mellitus. Diabet Med 2000; 17: 487-8.

8. Rubinstein E, Kollef MH, Nathwani D. Pneumonia caused by methicillinresistant Staphylococcus aureus. Clin Infect Dis 2008; 46(Suppl 5): 378-85.

9. Purdy J, Jouve S, Yan JL, Balter I, Dartois N, Cooper CA, et al. Pharmacokinetics and safety profile of tigecycline in children aged 8 to 11 years with selected serious infections: a multicenter, open-label, ascending-dose study. Clin Ther 2012; 34: 496-507.

10. Wong KS, Chiu CH, Yeow KM, Huang YC, Liu HP, Lin TY. Necrotising pneumonitis in children. Eur J Pediatr 2000; 159: 684-8.

11. Lai JY, Yang W, Ming YC. Surgical management of complicated necrotizing pneumonia in children pediatr neonato. 2016; http://dx.doi.org/10.1016/j. pedneo.2016.06.002

12. Tsai $\mathrm{Y}, \mathrm{Ku} \mathrm{YH}$. Necrotizing pneumonia: a rare complication of pneumonia requiring special consideration. Curr Opin Pulm Med 2012; 18: 246-52. 